\title{
Curriculum Design of Tourism Information Technology Application Based on Constructivism
}

\author{
Xiaohui Wang ${ }^{a^{*}}$, Xiaoli Liu ${ }^{b}$, Kewei Lei ${ }^{\mathrm{c}}$ and Qihong Tan ${ }^{\mathrm{d}}$ \\ School of leisure management, Xi'an Eurasia University, Xi'an, 7100 65,China \\ awxh2324@126.com, 'liuxiaoli@eurasia.edu, 'leikewei@eurasia.edu, dtanqihong@eurasia.edu
}

Keywords: Tourism information technology; structural equation; knowledge sharing; influencing factors

\begin{abstract}
To explore the influencing factors on the students of tourism information technology application study. Selection of knowledge sharing, knowledge interaction and other indicators, based on the field survey data, using the methods of structural equation, constructing the course learning factors conceptual model, with the AMOS 20 model parameter estimation and validation. The results show that the knowledge on students learning attitude the most obvious effect, the direct effect coefficient is 0.88 , the total effect coefficient for 0.92 . followed by easy operation and social recognition. Knowledge sharing and knowledge interaction both have positive effects on other variables.
\end{abstract}

\section{Introduction}

Constructivism holds that knowledge is not taught by teachers, but learners in certain contexts that the social and cultural background, with the help of other people (including teachers and learning partners) help, use the necessary learning materials, through the construction of meaning [1-3].Psychologists have established the basic model of human learning process, namely, the reaction model, referred to as S--R model [4-6]. It consists of five elements: the driving force, the stimulus, the cue, the response and the reinforcement.

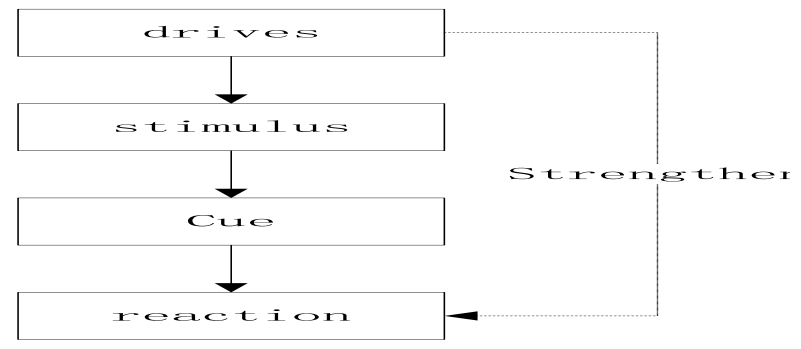

Figure 1. Schematic diagram of learning process model

In the course of the application of tourism information technology, there will also be self-motivation, external stimulation, reaction and reinforcement of such a learning process. So of the students in teaching, we should pay attention to the interest, stimulates the student to continue to increase their human capital value desire, so as to promote the students' interest in learning, the correct guidance, ultimately became a director of socially useful talents. Therefore, in the teaching process to explore the interests of students, and external incentives, will effectively improve the efficiency of learning. In this paper, the survey data of the students majoring in Tourism Management Based on the structural equation method, analyze the influencing factors of students' learning force, stimulus and effect, to provide the reference for the tourism information technology curriculum teaching. 


\section{Model Construction and Data Collection}

Model Construction. This paper discusses the factors that influence the students' active learning of tourism information technology, and the influence factors are various. Because the structural equation can reflect the relationship of variables indirectly and directly, the structural relationship between latent variables can be analyzed in the process of measuring error. Therefore, the construction of learning influence factors model.

Based on the Davis (1989) proposed the technology acceptance model as the theoretical basis, combined with literature research and expert advice on selecting [7-10], knowledge sharing, knowledge interaction, knowledge, easy operation, social recognition, learning attitude and learning motivation as sharing variables. To construct the model of influencing factors of course of study and put forward the research hypothesis is as follows (the conceptual model in Figure 1):

H1: knowledge sharing has a positive impact on the usefulness of knowledge;

$\mathrm{H} 2$ : knowledge sharing has a positive impact on social recognition;

H3: knowledge interaction has a positive impact on the usefulness of knowledge;

H4: knowledge interaction has a positive impact on the convenience of operation;

H5: the usefulness of knowledge has a positive impact on learning attitude;

H6: there is a positive impact on the learning attitude;

H7: social recognition has a positive impact on learning attitude;

H8: learning attitude has a positive impact on learning motivation

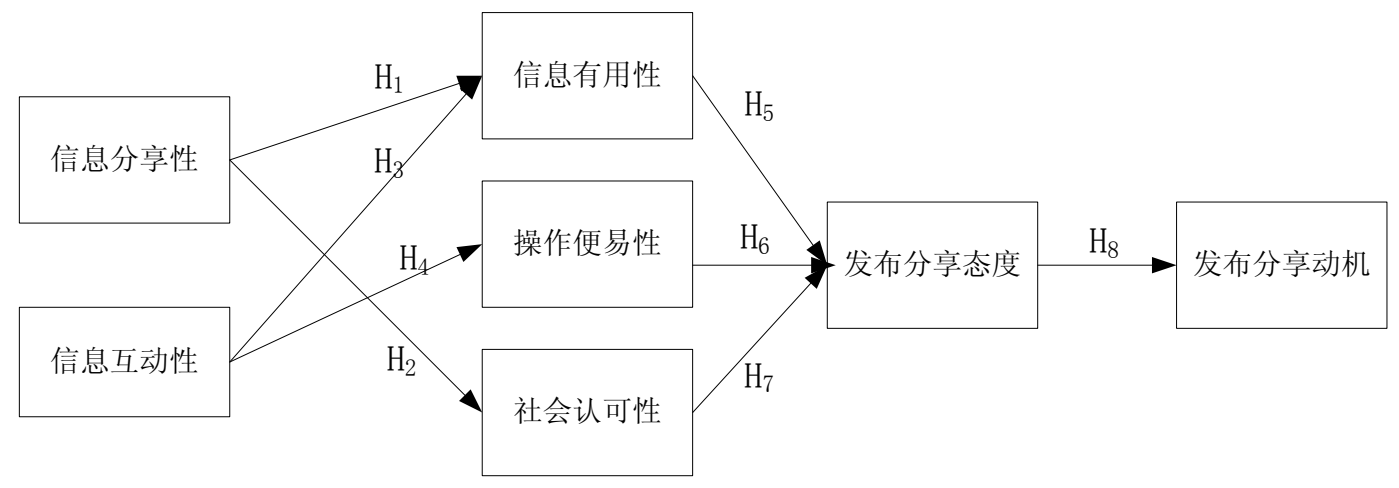

Figure 2. Conceptual model of structural equation

Data Acquisition. The questionnaire is divided into two parts: basic information and related observational variables and observation variables research design table 1 scale design using Liker five point scale method is very general, not consent, consent, consent, very not agree to five, the score was 5 points to 1 points. A questionnaire use online fill in the way, and issuing a formal network questionnaire in December 20, 2016, the recovery date is January 12, 2017, delete invalid questionnaire, a total of 263 valid questionnaires. The survey samples meet the structural equation model analysis. 
Table 1 Questionnaire design

\begin{tabular}{|c|c|}
\hline Latent & Variable \\
\hline convenience of operation & $\begin{array}{l}\text { 1.Operation interface is easy to use } \\
2 \text { The operating system is well organized } \\
{ }_{3} \text { The operating system design is very clear, very organized }\end{array}$ \\
\hline knowledge sharing ${ }_{1}$ & $\begin{array}{l}{ }_{1} \text { Like everyone together to discuss } \\
{ }_{2} \text { Like to help others by sharing knowledge } \\
{ }_{3} \text { Share knowledge with others in all kinds of learning activities } \\
{ }_{4} \text { When you are in trouble, you may want to share the experience of } \\
\text { others }\end{array}$ \\
\hline knowledge interaction $_{2}$ & $\begin{array}{l}{ }_{5} \text { Everyone expects to gain knowledge } \\
{ }_{6} \text { Class members are willing to evaluate or respond to various problems } \\
7 \text { Interaction with others can enhance my preference for the course } \\
{ }_{8} \text { Sharing knowledge with others can increase the recognition of others in } \\
\text { my class } \\
9 \text { Interacting with other members can help me find a solution to the } \\
\text { problem }\end{array}$ \\
\hline $\begin{array}{l}\text { the usefulness of } \\
\text { knowledge }_{3}\end{array}$ & $\begin{array}{l}{ }_{10} \text { Interaction with other members can improve my knowledge or } \\
\text { skills } \\
{ }_{11} \text { Sharing knowledge, I have confidence in the knowledge or skills of } \\
\text { the participating members } \\
{ }_{12} \text { Interaction with other members can expand my circle of } \\
\text { communication }\end{array}$ \\
\hline social recognition $_{4}$ & $\begin{array}{l}{ }_{13} \text { In a variety of learning environments, interacting with other people } \\
\text { is } \\
\text { very enjoyable and relaxing } \\
{ }_{14} \text { Sharing knowledge to help others feel good } \\
{ }_{15} \text { It's fun to share with others }\end{array}$ \\
\hline
\end{tabular}

\section{Empirical Results and Analysis}

Model Test. The concept model using AMOS 20 to estimate the constructed (Fig. 2) for parameter estimation (Table 2). At the same time, whether the parameter test model results with statistical significance, by means of $t$ test method for significant test of the path coefficients, the results are shown in Table 3. 
Table 2 Structural equation model parameters estimation

\begin{tabular}{llllll}
\hline \multicolumn{1}{l}{ OLV } & \multicolumn{1}{c}{ ELL } & VLV & Direct effect & Total effect \\
\hline 1 & $(4)$ & $0.81(16.25)$ & $(1) \rightarrow(3)$ & $0.62(6.88)$ & $0.62(6.88)$ \\
2 & $(4)$ & $0.68(11.07)$ & $(1) \rightarrow(5)$ & $0.81(7.39)$ & $0.79(7.33)$ \\
3 & $(4)$ & $0.72(11.39)$ & $(2) \rightarrow(3)$ & $0.56(4.21)$ & $0.62(5.28)$ \\
1 & $(1)$ & $0.62(5.06)$ & $(2) \rightarrow(4)$ & $0.73(5.07)$ & $0.73(5.07)$ \\
2 & $(1)$ & $0.73(11.32)$ & $(3) \rightarrow(6)$ & $0.92(7.51)$ & $0.90(7.83)$ \\
3 & $(1)$ & $0.79(12.01)$ & $(4) \rightarrow(6)$ & $0.85(6.41)$ & $0.83(6.91)$ \\
4 & $(1)$ & $0.90(19.69)$ & $(5) \rightarrow(6)$ & $0.72(4.78)$ & $0.67(5.74)$ \\
5 & $(2)$ & $0.89(18.14)$ & $(6) \rightarrow(7)$ & $0.82(6.32)$ & $0.80(6.76)$ \\
6 & $(2)$ & $0.63(9.72)$ & & & \\
7 & $(2)$ & $0.69(16.25)$ & & & \\
8 & $(2)$ & $0.86(15.64)$ & & & \\
9 & $(3)$ & $0.84(13.02)$ & & & \\
10 & $(3)$ & $0.88(16.89)$ & & & \\
11 & $(3)$ & $0.71(12.76)$ & & & \\
12 & $(3)$ & $0.77(15.34)$ & & & \\
13 & $(5)$ & $0.69(10.49)$ & & & \\
14 & $(5)$ & $0.73(11.55)$ & & & \\
15 & $(5)$ & $0.83(15.81)$ & & & \\
\hline
\end{tabular}

Note: OLV: Observation and latent variables ELL: External load Latent VLV: variable and latent variable

Table 3 Path coefficients of structural model and hypothesis verification

\begin{tabular}{lccl}
\hline Hypothesis & Corresponding hypothesis & $\mathrm{t}$ - Value & Result \\
\hline$(1) \rightarrow(3)$ & H1 & 8.39 & establish** \\
$(1) \rightarrow(5)$ & H2 & 2.80 & establish** \\
$(2) \rightarrow(3)$ & H3 & 2.63 & establish** \\
$(2) \rightarrow(4)$ & H4 & 3.48 & establish* \\
$(3) \rightarrow(6)$ & H5 & 3.87 & establish** \\
$(4) \rightarrow(6)$ & H6 & 3.41 & establish** \\
$(5) \rightarrow(6)$ & H7 & 1.98 & establish** \\
$(6) \rightarrow(7)$ & H8 & 5.05 & establish** \\
\hline
\end{tabular}

Note: $* * *$ are expressed at $5 \%$ and $1 \%$ significance levels by $\mathrm{t}$ test

Results Analysis. Table 2 shows the affecting factors in the application of information technology in tourism study, the influence of knowledge is the most significant, the direct effect is 0.88 , and the total effect is 0.92 . The reason is the high degree of recognition of the students of electronic information technology. The technology can effectively help easy operation of you. The effects were 0.85 and 0.83 ; most respondents think that the network has the advantages of simple operation, user-friendly design, easy to learn. Finally, the social recognition also has a positive impact on learning attitude, the application of information technology to improve the quality of the work on the one hand, on the other hand, to increase the work of the community.

With the variables, all the observed variables are the latent variable is the load coefficient. The value 4, 510 of the positive effects is larger than other variables. They are $0.90,0.89$ and 0.88 , respectively. Based on the public knowledge, $90 \%$ of the students in difficulties, turn to other students, $89 \%$ of students expect to get help. $88 \%$ of the students thought to enhance their skills.

\section{Curriculum Model Design}

Based on the structural equation model, this paper analyzes the influencing factors of the application of tourism information technology curriculum. According to the analysis results, we can 
understand the learning motivation, stimulation and so on. The teaching mode of the course is as follows:

Project Research Model. The project research mode is to set up the corresponding scenario setting by setting a project or topic in the classroom [11]. This project can be an external driving force for students to learn. Drive students to complete the learning tasks, learning content.

Problem Solving Model. By presenting a comprehensive view of the problem, and solving the problem as a classroom teaching [12]. As a stimulus for students, teachers help students to explore the problems related to the teaching process or by the participants. To enhance students' ability to apply theory to practice and concrete analysis of the actual of the actual problems.

Situational Teaching Model. Situational teaching mode is to guide the students into the scene through the way of setting the scene in the classroom teaching process. Situational teaching is still the main driving force in the development of the teaching model.

\section{Conclusions}

This paper put attempts to study the reaction model of Constructivism in the teaching practice, using the methods of structural equation, hoping to enhance the students' learning motivation, improve the ability of independent learning, and ultimately the formation of learning practice in the virtuous cycle of learning.

\section{Acknowledgements}

This work was partly supported by the Curriculum reform project of School of leisure management.

\section{References}

[1] Ajzen I, Fishbein M. Attitude-behavior relations: A theoretical analysis and review of empirical research[J]. Psychological Bulletin, vol.84(1977)No.5,p.888-918.

[2] Porcaro P A, Jackson D E. Curriculum Design of a Flipped Classroom to Enhance Haematology Learning[J]. Journal of Science Education and Technology, vol.25(2016)No.3,p.345-357.

[3] Galan-Muros V, Plewa C, Davey T. Plewa, C.; Davey, T.; Galán-Muros, V. (2015) "Engaging Business in Curriculum Design and Delivery - A Higher Education Institution perspective", Higher Education (accepted for publication).[J]. Higher Education, vol.70(2015)No.1,p.35-53.

[4] Brooman S, Darwent S, Pimor A. The student voice in higher education curriculum design: is there value in listening?[J]. Innovations in Education and Teaching International, vol. 246(2015)No.6,p.1-12.

[5] Pullin, Patricia. Culture, curriculum design, syllabus and course development in the light of BELF[J]. Journal of English as a Lingua Franca, vol.4(2015)No.1,p.31-53.

[6] Smirnov, Alexander, Shilov, Nikolay, Kashevnik, Alexey, et al. Cyber-physical infomobility for tourism application[J]. International Journal of Information Technology and Management, 2016No.16.

[7] Stepanyuk O O, Babikova K O, Isayenko V M. The role of information technology in the rural green tourism organization [J]. Balanced Nature Using, (2016)No. 4.

[8] Ii G C B, Kumar A. Explaining consumer acceptance of handheld Internet devices[J].Journal of Business Research,vol.58(2005)No.5,p.553-558.

[9] Dnah m. body, Nicole B. Ellison. Social Network Sites: Definition, History, and Scholarship [J]. Journal of Computer- Mediated Communication, vol.13 (2007)No.1,p.210-230. 
[10]Zhihui Li, Zhihui Li. Discussion on Application of Information Technology in Internship in Hotel and Tourism Management [J]. Human Molecular Genetics, vol. 23 (2014)No.8,p.2198-2209.

[11]Eastin M S, Larose R. Alt. support: modeling social support online [J]. Computers in Human Behavior, vol. 21 (2005) No.6, p.977-992.

[12] Yu R. Design and Realization of the Personalized Data in Tourism Business Website [J]. Applied Mechanics \& Materials, (2014)p. 5780-5782. 